\title{
Does Portfolio Diversification Affect Performance of Balanced Mutual Funds in Kenya?
}

\author{
Dr. Cyrus Iraya, Senior Lecturer \\ Fernandes Juma Wafula, MBA Finance Student
}

Department of Finance and Accounting, University of Nairobi, Kenya

Doi: 10.19044/esj.2018.v14n4p158 URL:http://dx.doi.org/10.19044/esj.2018.v14n4p158

\begin{abstract}
Literature provides conflicting results on the effect of diversification on performance of mutual funds with some studies showing a positive relationship (Markowitz, 1952; Muriithi, 2005; Kagunga, 2010), others negative (Chang \& Elyasiani, 2008; Fiegenbaum \& Thomas, 1998) and still others showing that there is no relationship between the two variables (Loeb, 1950). It is with this background that this study sought to establish the effect of diversification on performance of mutual funds in Kenya. The study took a descriptive research design approach on weekly performance of a sample of 7 balanced mutual funds for the year 2013.The study used secondary data sources available at the Capital Market Authority offices and from each mutual funds. The portfolio return was determined by computing the changes in prices of the balanced fund as traded at the Nairobi Securities Exchange (NSE) while diversification was determined from the level of Unsystematic Risk in the Performance. The study used the Ordinary Least Squares (OLS) multiple linear regression equation. Control variables of the size and age of the fund were introduced in the regression model. The results indicated the existence of a positive relationship between the Unsystematic Risk and Performance of balanced mutual funds with a beta coefficient of $0.069(\mathrm{t}=4.971, \mathrm{p}<0.5$. This implies that the lower the diversification the higher the performance of mutual funds.
\end{abstract}

Keywords: Diversification; Portfolio Performance; Unsystematic Risk, Balanced Mutual Funds

\section{Introduction}

Investors are generally risk averse and will do anything within their power to minimize risk without affecting the level of return that they can receive from their investment. One of the ways to achieve this is by diversifying the investment portfolio into many assets classes such as stocks, 
bonds and real estate. Diversification is the holding of a combination of assets which are not positively correlated such that in the event of poor fortunes of one asset, the investor can be compensated by the good fortunes of the other assets. Markowitz (1952) observed that diversification helps in the reduction of portfolio risk and cushions the portfolio from potentially catastrophic events such that in the event of failure of one of the constituent investments the investor falls back to the good fortunes that the other constituent investments would record hence ensuring that the entire portfolio value and returns remains good.

According to Markowitz Modern Portfolio Theory (MPT), an investment bears two types of risk: systematic and unsystematic (Markowitz, 1952; Sharpe, 1964). Systematic risk is the risk inherent in the volatility of the entire capital market, while specific (unsystematic) risk is associated with the volatility of an individual security. Investors may assemble portfolios in such a way that the specific risk carried by any individual security within the portfolio is offset by the specific risk carried by another. This is referred to as diversification. Sharpe (1964) holds that efficient capital markets reward investors for bearing systematic risk, but because diversification is possible, investors are not rewarded for bearing specific risk. That is, when a fund carries specific risk, it fails to reach the efficient frontier, wherein the risk/return trade-off is optimized.

Portfolio return on the other hand is the combination of the expected returns, or averages of probability distributions of possible returns, of all the assets in an investment portfolio. These overall returns usual give a better reward to an investor than when investments are held in isolation. Kamwaro (2013) contends that there is a strong relationship between financial performance and the size of investment one holds in a portfolio thereby contributing to the fact that diversification affects performance. This thinking has led to the development of many collective investment schemes or mutual funds around the world.

Mutual funds constitute a pool of funds that are managed on behalf of investors by professional money managers. In Kenya the term unit trusts and collective investment schemes are interchangeably used to refer to mutual funds. The fund management industry is a key sector that invests funds under their control for both the private and public sectors in Kenya. The fund management industry in Kenya is relatively young having taken off with the passage of the Capital Markets Amendment ACT (2000), which promotes, regulates and facilitates the development of an of an orderly, fair and efficient Capital Markets. 


\section{Research Problem}

The investments environment within which the mutual funds operate are faced with a number of challenges chief among them is the risk. Risk basically is the variability of the portfolio return as a result of unforeseen circumstances. Diversification of the investment assets forms a critical component of a fund manager's strategy in their endeavor to improve the performance. Generally, there is a positive relationship between the number of assets held by a fund manager in an investment portfolio and the portfolio return since as the number of assets increase, the portfolio risk reduces which in the long-run improve the fortunes of an investor.

Fund management in Kenya is a relatively new investment frontier and limited information has been published on their performance. Despite their late entry in the market, mutual funds have grown in leaps and bounds in the recent past. There are currently about twenty six fund managers registered by the CMA which further shows the level of importance the mutual funds play in the Kenyan economy. The recent increase in the number of players and type of funds that are available to individual investors make a lot of theoretical and practical significance. A lot of studies have been done on the relationship between risk and returns from scholars like Sharpe (1965) and Firth (1977). The main finding in most of these studies is that there is a positive relationship between risk and return. The risk return trade off concept therefore means that investors get rewarded through a risk premium for taking additional risk. However exceptions have been noted in this conclusion .Bowman (1980) discovered that within most industries risk and return were negatively correlated. Fiegenbaum and Thomas (1998) also observed a negative relationship between risk and return.

A number of studies have been done in Kenya on fund management firms. Muriithi (2005) carried out an evaluation of risk and returns of equity mutual funds in Kenya from the period 1st January to 30th June 2005 .He established that out of the mutual funds studied the Old Mutual Equity Fund and the African Alliance Balanced Fund did not exhibit a positive risk return relationship which is an indication that unit holders are risk averse and expect to be compensated with high returns for any additional risk undertaken. Thuo (2011) tested the risk return relationship of mutual fund market in Kenya. He concluded that a negative beta which is statistically significant was obtained for the GDP growth rate. This implied that a decrease in the economic growth rate is an increase in the risk faced by investors hence they will demand a higher rate of return. Ngene (2002) carried out an investigation into the portfolio performance measures used by pension funds mangers and the challenges they face in portfolio management in Kenya. He established that most investment managers are aware of the portfolio performance measures yet only one of the nine respondents use the measures in pension fund 
management. Maina (2003) researched on risk and return of investments held by insurance Companies in Kenya from January 1997 to December 2001. From his findings, he established that there is very little correlation between return and risk of investments held by Kenyan insurance companies. Only investments in secured loans had a positive relationship between return and risk.

However, very limited information has been published on the effect of diversification on portfolio return among registered mutual fund firms, what number of assets are ideal to ensure a fully diversified portfolio that can eliminate all the risks and why some mutual funds still make losses or record less returns despite being diversified and whether there are other factors that can influence the portfolio return apart from diversification. Therefore, the research aims to determine the relationship between diversification and portfolio return of investments held by registered mutual funds in Kenya. Towards providing answers and filling any gaps to these issues, the research evaluated how the level of diversification affects portfolio return held by registered fund management firms in Kenya. This study will assist in answering the research question; what is the relationship between diversification and portfolio return among fund management firms in Kenya?

\section{Objectives of the Study}

The objective of this study was to determine the effect of diversification on performance of mutual funds in Kenya.

\section{Theoretical Foundation}

Investor looks forward to getting good return for their investment as a compensation or reward for taking a risk in an investment. The study was guided by the modern portfolio theory and capital asset pricing theory to demonstrate the effect of diversification on portfolio return of mutual funds. Markowitz (1952) developed the basic portfolio theory, he derived the expected rate of return for a portfolio of assets and an expected risk measure. It emphasizes how risk-averse investors can construct portfolios to optimize or maximize expected return based on a given level of risk, emphasizing that risk is an inherent part of higher reward. According to the theory, it's possible to construct an efficient frontier of optimal portfolios offering the maximum expected return for a given level of risk. There are four basic steps involved in portfolio construction: security valuation, asset allocation, portfolio optimization and performance measurement. The implication of MPT is that a rational investor will not invest in a portfolio if a second portfolio exists with a more favorable risk-expected return profile. The mutual fund managers will therefore assemble assets in their portfolio that are likely to record high portfolio return within any given level of risk. 
Capital Asset Pricing Model (CAPM) was developed independently by three scholars Sharpe 1964, Lintner 1965, Treynor 1961. The model is based on portfolio theory and demonstrates how risk and return could be linked together and also specifies the nature of risk/ return relationship. In such a simple world, Tobin (1958) super-efficient portfolio must be the market portfolio. All investors will hold the market portfolio, leveraging or deleveraging it with positions in the risk free asset in order to achieve a desired level of risk. For any security or portfolio the CAPM decomposes and quantifies the total risk of a portfolio or individual assets into two components: diversifiable (Unsystematic risk) and non- diversifiable risk (systematic risk). Systematic risk is the risk of holding the market portfolio. As the market moves, each individual asset is more or less affected. To the extent that any asset participates in such general market moves, that asset entails systematic risk. Unsystematic (specific) risk is the risk which is unique to an individual asset. It represents the component of an asset's return which is uncorrelated with general market moves (Lintner, 1965). Unsystematic risk is the risk to an asset's value caused by factors that are specific to an organization, such as changes in senior management or product lines. In general, unsystematic risk is present due to the fact that every company is endowed with a unique collection of assets, ideas and personnel whose aggregate productivity may vary.

\section{Empirical Evidence}

Several studies have been carried out on the effect of diversification on performance resulting in different conclusions. Markowitz (1952) observes that by investing in more than one stock, an investor can reap the benefits of diversification by reducing the riskiness of portfolio. The risk in a portfolio of diverse individual stocks will be less than the risk inherent in holding any one of the individual stocks (provided the risks of the various stocks are not directly related). This will in the long run ensure that the level of return an investor will earn in a portfolio is more certain and higher than if they held their investments in isolation. The ability to reduce firm-specific risk in a portfolio depends on the relative correlation of the assets held in the portfolio. The lower the Correlation between assets held in a portfolio by an investor, the higher the ability of an investor to reduce risk and increase the expected returns.

Muriithi (2005) evaluated the relationship between risk and returns of equity mutual funds in Kenya. In addition, the study also sought to compare the performance of Kenyan equity mutual funds with the stock market as a whole using the NSE20 share index as the benchmark. In order to achieve these objectives, secondary data was used to generate each mutual fund's returns and risk. Regression analysis was used to derive the beta. The 
coefficient of variation, Sharpe model, Treynor model and the Jensen model were used to determine the relative performance of the sample mutual funds. The results of the study indicated that there exists a positive risk-return. The risk adjusted performance measures, showed that the Balanced Fund had the worst performance when compared to the Equity Fund and the market. However, both the coefficient of variation and the Sharpe Index indicated that the Equity Fund performed worse than the market portfolio. While the Treynor index and the Jensen alpha ranked the Equity Fund as having performed better than the market portfolio as represented by the NSE20 Index. The findings indicate that the investment manager of the Equity Fund, in an effort to select undervalued securities or to time the market, holds a portfolio that is less than fully diversified, and as such contains some diversifiable risk.

Kagunga (2010) investigated whether unit trusts in Kenya have better performance compared to that of market portfolio, given their systematic risk. The population of study consisted of all the Unit Trusts in Kenya. The Nairobi 20 share index was used in estimating the performance of a market portfolio. Data on net asset value and dividend paid by unit trusts was collected from offices of respective unit trusts schemes. Data on estimate of dividend received on the market portfolio, and the 20 share index was collected from the Nairobi Stock Exchange. Data on market interest rates, interbank lending rates and free rates was collected from the Central Bank of Kenya. By carrying out regression tests, he confirmed that there was a strong relationship between unit trust return and that of the market.

Maina (2011) conducted a study to assess the relationship between unit trusts performance and the asset allocation in Kenya for a selected sample of the companies licensed by the Capital Markets Authority under the Collective Investment Schemes. The sample consisted of 12 companies with which a questionnaire was administered. The performance was regressed against asset allocation and empirically analyzed. He found out a positive correlation between performance and equity asset allocation in the management of Unit Trusts in Kenya where Fund managers employed diversification in the investment of the client money.

Mutuku (2011) conducted a study to determine the relationship between portfolio composition and risk and return among fund management firms in Kenya. The research was studied through the use of a descriptive survey. The population of the study was 18 registered fund managers operating in a Kenya at that time. Both secondary data and primary data was used to carry out this study. The secondary data was collected from the registered fund managers' financial statements, other published sources and annual returns to regulatory authorities like Capital Markets Authority and Retirement Benefits Authority. Primary data was collected by a drop and pick questionnaire. The study concludes that the fund management firms determine the percentage 
return of the investment portfolio. The method used by the firms in determining percentage rate of return was geometric or time weighted returns. Buster (2012) studied the relationship between asset allocation and financial performance of mutual funds in Kenya. The population of study consisted of all approved Collective Investment Schemes in Kenya that deal with Mutual funds and invest in equities. There were seven in number during the time of study that deal with equity fund. The NSE 20 share index was used in estimating the performance of a mutual fund's performance. The index was calculated using equities of 20 companies; this clearly indicated the need to restrict the study to mutual funds that invests only in shares. The study found out that there was a difference between the performance of unit trusts and the market. This was illustrated especially in the year 2011, where the stock market slumped in its performance while that of the unit trusts improved in its returns by $18 \%$ as compared to the previous years. However, in the year 2010 and 2011 both returns from the stock market and the unit trust recorded an upward trend while in 2010 , both were affected by external factors namely the post-election violence to record a downward trend in performance. The findings show that unit trusts performed well over the period of study. In most of the instances, the market trailed behind the performance of unit trusts. The fact that unit trust outperformed the market can be attributed to the fact that fund managers could be in a position to predict stock prices based on several fundamental variables such as initial dividend yields, market capitalization, price earnings ratios, and price to book value ratios. This implied that fund managers may have access to enough private information to offset their expenses. These results are consistent with the notion that mutual funds are efficient.

Kamwaro (2013) sought to determine the impact of investment portfolio choice on financial performance of investment companies. The study took a causal research design approach and study entailed a census of all the investment companies operating in Kenya and listed in the Nairobi Securities Exchange. There were four investment companies listed in Nairobi Securities Exchange during the period of study between the years 2007 to year 2011.Secondary data sources available at the companies' books of account and the NSE or Capital Market Authority offices was used. The study used the multiple linear regression equation and the method of estimation was Ordinary Least Squares (OLS) so as to establish the impact of investment portfolio choice on profitability of investment companies. The study revealed that investment portfolio choice affects the financial performance of investment companies listed in the Nairobi Securities Exchange. The study found that investment in bonds positively influences the financial performance of investment companies listed in the NSE. The study also found that investment in real estate and equity by investment companies positively impacted in the 
financial performance, it was found that size of the company positively impacted in the financial performance of investment companies. There is need for the management of investment companies to have solid organization structure, organization structure will influence their investment portfolio choice which impact on their financial performance.

Maina (2013) evaluated the effect of portfolio characteristics on financial performance of unit trusts in Kenya. The study applied the multifactor model envisioned by Fama and French. The model provided a platform to investigate into the impact of certain characteristics of a fund to performance in this case focusing on size, value versus growth and momentum factors. The study utilized descriptive analysis and a multi-factor model. The target population was 14 unit trusts that consisted of equity-based funds in Kenya for the period 2008 to 2012 with complete set of data for 24 months. From the findings, the study established that there is a strong relationship between all the four factors under study and funds' return hence all the factors had a significant effect on performance. The study also found out that the beta values of the model showed that the sampled funds were more exposed to small stocks, value rather than growth stocks and consistent positive future performing funds. The study further established that there was a strong positive relationship between portfolio characteristics and unit trusts financial performance further supporting the robustness of the multi-factor model.

\section{Research Methodology}

This study took a descriptive research design approach. Descriptive research study is typically concerned with determining the relationship between two variables. Descriptive research portrays an accurate profile of persons, events, or situations (Robson, 2002). Being that the study sought to find out the effect of diversification on portfolio return, a descriptive research design was deemed appropriate. The population for the study was 15 balanced mutual fund as per the CMA listing in July 2014. A sample of 7 diversified Balanced Funds was selected which is believed that it represents the population in true sense.

The study used weekly secondary data on the unsystematic risk and portfolio returns for the year 2013. The Secondary data was chosen owing to the fact that they are cheaper and more readily available than primary data. Secondary data was collected from the mutual funds' reports at the capital market authority and from each of the fund managers.

\section{Data Analysis Techniques}

The study used the multiple linear regression equation to establish the effect of diversification on performance of mutual funds. The regression equation estimated the model with portfolio return as the dependent variable 
and unsystematic risk, size of the fund and age of the fund as independent variables.

The model used in the study is given as:

$E(R)_{p}=a+b_{1} U+b_{2} S+b_{3} A+e$

Where

$\mathrm{E}\left(\mathrm{R}_{\mathrm{p}}\right)$ is Portfolio Return-Measured by Jensen ratio:

$\alpha=E\left(R_{p}\right)-\left(E\left(R_{f}\right)+\beta_{p}\left(E\left(R_{m}\right)-E\left(R_{f}\right)\right)\right.$

$\mathrm{U}$ is the Unsystematic Risk-Measured by Fama Net Selectivity Measure as follows:

$$
U=\left(\sigma_{p}-\beta_{p}\right)\left(E\left(R_{m}\right)-E\left(R_{f}\right)\right)
$$

(Note: The higher the $U$ for a specific mutual fund, the lower the diversification level of the fund)

a is the Constant or intercept

$b_{i}$ is the Slope (Beta coefficient) for $\mathrm{Xi}$

$\mathrm{S}$ is the size of the Mutual Fund (control variable) measured by LOG (Fund Total Assets)

A is the Age of the Mutual Fund-Measured by number of years of the Fund $\mathrm{e}$ is the Error term

$\mathrm{U}$ is the unsystematic risk in a fund

$\sigma_{\mathrm{p}}$ is fund p's historic standard deviation,

$\beta_{\mathrm{p}}$ is fund p's historic beta

$\mathrm{E}\left(\mathrm{R}_{\mathrm{m}}\right)$ is the expected market returns (approximated by average return on NSE 20 share index)

$\mathrm{E}\left(\mathrm{R}_{\mathrm{f}}\right)$ is the expected risk free return (approximated by average return on 91 treasury bills).

\section{Results of Research}

From the descriptive statistics shown on Table 1 below, portfolio returns has a mean of 5.26181 and a standard deviation of 0.00864 . Unsystematic risk has a mean of 3.52344 and a standard deviation of 5.03154, Size of fund has a mean of 8.40400 and a standard deviation of 0.000 , Age of fund has a mean of 6.53000 and a standard deviation of 0.30310 . The size of fund remains constant with zero deviation from the means since it's a control variable of the study. The unsystematic risk and age of fund shows some deviation from the mean with unsystematic risk showing the greatest deviation since it has the highest effect on the portfolio return. 
Table 1: Descriptive Statistics

\begin{tabular}{|c|c|c|}
\hline Variables & Mean & Std Deviation \\
\hline $\begin{array}{c}\text { Dependent Variable } \\
\text { Portfolio Returns } \\
\text { Independent Variables }\end{array}$ & 5.26181 & 0.00864 \\
Unsystematic Risk-X1 & & \\
$\quad$ Size of Fund-X2 & 3.52344 & 5.03154 \\
Age of Fund-X3 & 8.40400 & 0.00000 \\
& 6.53000 & 0.30310 \\
\hline
\end{tabular}

Multiple linear regressions was established through Ordinary Least Squares (OLS) so as to determine the effect of diversification on performance of mutual funds. The study covered a period of 52 weeks for the year 2013. The findings are as follows:

Table 2: Model Summary

\begin{tabular}{|c|c|c|c|c|}
\hline Model & $\mathrm{R}$ & $\mathrm{R}$ Square & Adjusted R Square & $\begin{array}{c}\text { Std. Error of the } \\
\text { Estimate }\end{array}$ \\
\hline 1 & $.653 \mathrm{a}$ & .426 & .422 & 1.36132 \\
\hline
\end{tabular}

Adjusted R squared is coefficient of determination which tells us the variation in the dependent variable due to changes in the independent variable. From the findings in the above table, the value of adjusted $\mathrm{R}$ squared was 0.422 , an indication that there was variation of $42.2 \%$ on the portfolio return due to changes in unsystematic risk, age of fund and the fund size at $95 \%$ confidence interval. This shows that $42.2 \%$ changes in portfolio return of mutual fund could be accounted for by unsystematic risk, age of fund and the size of fund. $\mathrm{R}$ is the multiple correlation coefficient which shows the relationship between the study variables. The findings show that there was a fairly strong positive relationship between the study variables as shown by the $\mathrm{R}$ of 0.653 .

Table 3: Analysis of Variance

\begin{tabular}{|cc|c|c|c|c|c|}
\hline & Model & Sum of Squares & df & Mean Square & F & Sig. \\
\hline \multirow{4}{*}{1} & Regression & 495.993 & 3 & 165.331 & 89.214 & $.000 \mathrm{~b}$ \\
& Residual & 667.150 & 360 & 1.853 & & \\
& Total & 1163.144 & 363 & & & \\
\hline
\end{tabular}

From the ANOVA statistics in table above, the sum of squares due to regression is 495.993 while the mean sum of squares is 165.331 with 3 degrees of freedom. The sum of squares due to residual is 667.150 while the mean sum of squares due to residual is 1.853 with 360 degrees of freedom. The value of $\mathrm{F}$ calculated is 89.214 and the significance value is $0.000 . \mathrm{p}<0.05$ is an indication that unsystematic risk, age of fund and size of fund were significantly influencing portfolio return of mutual funds in Kenya. 
Table 4: Model Coefficients

\begin{tabular}{|cc|c|c|c|c|c|}
\hline \multirow{2}{*}{ Model } & \multicolumn{2}{|c|}{$\begin{array}{c}\text { Unstandardized } \\
\text { Coefficients }\end{array}$} & $\begin{array}{c}\text { Standardized } \\
\text { Coefficients }\end{array}$ & \multirow{2}{*}{ Sig. } \\
\cline { 3 - 5 } & B & Std. Error & Beta & & \\
\hline \multirow{4}{*}{1} & (Constant) & -1.150 & .825 & & -1.395 & .164 \\
& Unsystematic Risk & .069 & .014 & .204 & 4.971 & .000 \\
& Size of Fund & .899 & .103 & .358 & 8.738 & .000 \\
& Age of Fund & -.413 & .033 & -.526 & -12.644 & .000 \\
\hline
\end{tabular}

From the data in the above table the established weekly regression equation was

$$
\mathrm{Y}=-1.150+0.069 \mathrm{U}+0.899 \mathrm{~S}-0.413 \mathrm{~A}
$$

From the above regression equation, it was revealed that holding unsystematic risk, age of fund and size of fund to a constant zero, performance would stand at -1.150 , a unit increase in unsystematic risk would lead to increase in performance by a factor of 0.069 , unit increase in the size of fund will increase the performance by a factor of 0.899 whereas unit increase in age of fund would lead to -0.413 increase in performance of mutual fund.

\section{Conclusion and Recommendations}

From the findings the study revealed that diversification affect the performance of mutual funds.

The study revealed that lower diversification represented by the level of unsystematic risk positively influences the performance of mutual funds. This implies an inverse relationship between diversification and portfolio return and thus shows no major value in portfolio diversification. This study supports the work of Chang and Elyasiani (2008) and Fiegenbaum and Thomas (1998)

The current research focused on the mutual funds in Kenya. This excludes other industries hence future studies should consider diversification and returns in other industries such as media, insurance and even personal investment clubs. The research also investigated the effect of diversification on performance of balanced mutual funds, excluding other mutual funds such as money, equity markets among others. A research should be done on these other funds. One may also be interested to know the kind of strategies used by fund managers to select the efficient portfolio that will make them experience superior performance compared to the market.

\section{References:}

1. Bettis, R.A. \& Hall, W.K. (1982). Diversification strategy, accounting determined risk, and accounting determined return. Academy of Management Journal, 25, 251-264. 
2. Bowman, E.H. (1980). A risk return paradox for strategic management. Sloan Management Review 21, 17-31

3. Brinson, L. R. \& Beebower, G. L. (1986). Determinants of portfolio performance. Financial Analysts Journal, July/August, 42(3), 39-44

4. Buster, B.D. (2012). Relationship between asset allocation and financial performance of mutual funds in Kenya, Unpublished MBA Thesis, University of Nairobi.

5. Chang, M. S., \& Elyasiani, L. (2007). Product diversification and performance in the financial industry: Financial Holding Company expansion into insuarance activities. Presented at ARIA meeting in

6. Portland 2008

7. Christensen, H.K. \& Montgomery, C.A. (1981), Corporate economic performance: diversification strategy versus market structure. Journal of Strategic Management, 2, 327-347.

8. Fiegbaum, A., \& Thomas H. (1988). Altitudes towards risk and risk return paradox: prospect theory explanation. Academy of Management Journal, 31, 737 - 770

9. Ghysels, E.; P. Santa-Clara; and R. Valkanov. 2005. There is a riskreturn tradeoff after all. Journal of Financial Economics, 76(3), 509548.

10. Jacobson, R., (1987). The validity of ROI as a measure of business performance, American

11. Economic Review, 77, 3, June, 470-478.

12. Fama E., (1972). Components of investment performance. Journal of Finance, 27 (3), 551-567.

13. Jensen, M.C. (1968).The performance of mutual funds in the period 1945-1964. Journal of Finance, 23(2), 389-416.

14. Kagunga, P.K. (2010). Comparison of performance between unit trusts and a market portfolio of shares at Nairobi Stock Exchange, Unpublished MBA Thesis, University of Nairobi.

15. Kamwaro, E.K. (2013).The Impact of Investment Portfolio Choice on Financial Performance of Investment Companies in Kenya, Unpublished MBA Thesis, University of Nairobi.

16. Lintner, J. (1965). The valuation of risk assets and the selection of risky investments in stock portfolios and capital budgets. Review of Economics and Statistics. 47:1, 13-37.

17. Loeb, G.M., (1950). The battle for investment survival, John Wiley \& Sons.

18. Maina, P.K. (2003). Risk and Return of Investment held by Insurance Companies in Kenya, Unpublished MBA Thesis, University of Nairobi. 
19. Maina, R.W. (2011). Relationship between Unit Trusts performance and the asset allocation in Kenya, Unpublished MBA Thesis, University of Nairobi.

20. Maina R.W.(2013). The effect of portfolio characteristics on financial performance of unit trusts in Kenya. Unpublished MBA Thesis, University of Nairobi.

21. Markowitz, H. (1952). Portfolio selection. Journal of Finance, 7, 7791.

22. Modigliani, F.,\& Pogue ,G. (1974). An introduction to risk and return concepts and evidence. Part2, Financial Analysts Journal, 29, 449 470

23. Monteil, P. \& Reinhart, C. (1999). Do capital controls and macroeconomic policies influence the volume and composition of capital flows? Evidence from the 1990s. NBER Working Paper Series, March 1997.

24. Muriithi, D.K. (2005). An Evaluation of the Risk and Returns of Equity Mutual Funds in Kenya, Unpublished MBA Thesis, University of Nairobi.

25. Mutuku, F.M. (2011). Relationship between Portfolio Composition and Risk and Return among Fund Management Firms in Kenya, Unpublished MBA Thesis, University of Nairobi.

26. Ngene, G.M. (2002). Empirical Investigation into Portfolio Performance Measures by Pension Fund Managers and The Challenges They Face In Portfolio Management In Kenya, Unpublished MBA Thesis, University of Nairobi.

27. Palepu, K., (1985). Diversification strategy, profit performance, and the entropy measure. Strategic Management Journal, 6, (2), 239-255.

28. Robson, C. (2002). Real World Research, (2nd edition), Oxford, Blackwell .

29. Ross, Stephen (1976). The arbitrage theory of capital asset pricing. Journal of Economic Theory, 13 (3), 341-360.

30. Rumelt, R.P., (1974). Strategy, Structure, and Economic Performance (Cambridge, Mass., Harvard University Press).

31. Sharpe, W. F. (1964). Capital asset prices: a theory of market equilibrium under conditions of risk. Journal of Finance. 19(3), 425442

32. Thuo, K.T. (2011). Testing the risk return relationship of mutual funds market in Kenya, Unpublished MBA Thesis, University of Nairobi.

33. Tobin J. (1958). Liquidity Preference as Behavior Towards Risk. The Review of Economic Studies, 25 (2) 65-86

34. Treynor, J. L. (1961). Toward a Theory of Market Value of Risky Assets. Mimeo, subsequently 
35. published in Korajczyk, Robert A. (1999), Asset Pricing and Portfolios Performance: Models,

36. Strategy and Performance Metrics . London: Risk Books 